\title{
Analysis of Physico-Chemical Properties of Beeswax Produced in Bale Natural Forest, South-Eastern Ethiopia
}

\author{
Bekele Tesfaye $^{1, *}$, Desalegn Begna ${ }^{2}$, Mitiku Eshetu ${ }^{3}$ \\ ${ }^{1}$ Oromiya Agriculture Research Institute (OARI), Sinana Agriculture Research Center (SARC), Bale-Robe, Ethiopia \\ ${ }^{2}$ Oromiya Agriculture Research Institute (OARI), Holeta Bee Research Center (HBRC), Holeta, Ethiopia \\ ${ }^{3}$ Haramay University, Department of Animal and Range Sciences, Dire-Dawa, Ethiopia
}

Email address:

tbekele2001@gmail.com (B. Tesfaye)

${ }^{*}$ Corresponding author

\section{To cite this article:}

Bekele Tesfaye, Desalegn Begna, Mitiku Eshetu. Analysis of Physico-Chemical Properties of Beeswax Produced in Bale Natural Forest, South-Eastern Ethiopia. European Journal of Biophysics. Special Issue: Environmental Toxicology. Vol. 4, No. 5, 2016, pp. 42-46. doi: $10.11648 /$ j.ejb.20160405.11

Received: November 29, 2016; Accepted: January 3, 2017; Published: January 19, 2017

\begin{abstract}
The study was conducted to evaluate physico-chemical properties of beeswax from Bale natural forest Southeastern of Ethiopia in 2014/15. For analysis fifteen (15) crude beeswax samples each of 1 to $3 \mathrm{~kg}$ were obtained from three locations considering the different agro-ecologies of Bale and compared against to the national and international standards. The physico-chemical characters evaluated were: melting point, specific gravity, refractive index, volatile matter, acid value, saponification value, ester value, and acid to ester ratio. Although there were some significant variation $(\mathrm{P}<0.05)$ between the different agro-ecologies, all samples collected were found in the range of the national and international standard limits. The means results of beeswax sample collected were Melting Point (62.39 \pm 0.12$)$, Acid Value (22.33 \pm 0.39$)$, Ester Value (75.58 \pm 0.84$)$, Ester to Acid Ratio (3.38 \pm 0.07$)$, Saponification Value (98.04 \pm 0.86$)$, Specific gravity $(0.9598 \pm 0.001)$, Refractive Index (1.4426 \pm 0.0002$)$ and Volatile Matter $(0.3335 \pm 0.027)$. Results obtained in this study, indicate that beeswax obtained from Bale show excellent quality characters according to the national and international standards. Hence, it is advisable to utilize the potentials for export market with better improved technology interventions.
\end{abstract}

Keywords: Physico-Chemical, Properties, Beeswax, Quality, Natural Forest, Bale

\section{Introduction}

Beeswax is one of the oldest and most important items used by mankind. Today, beeswax is used for more than 300 purposes. Nowadays, with a world production of around 60,000 metric tons, beeswax has multiple uses in cosmetics, pharmacy, food and other industrial activities, apart from being used by beekeepers [1] As a result, the demand for beeswax is very high and it has been never satisfied. Because of its high demand and shortage in the world market, adulteration of beeswax with cheaper materials like animal fats, plant oils and petroleum sprits (paraffin wax) become a challenge for beeswax quality and its marketing [2-4].

The quality of beeswax is one of the main concerns of apiarists and a determinant factor in the beekeeping development. Ethiopia has huge apicultural resources that made it the leading beeswax producer in Africa, and one of the important beeswax exporters to the world market [4]. The authenticity of beeswax can also be determined by using physical-chemical parameters, such as melting point, density, acid value, Saponification value, ration number, ester value, iodine absorption number, and peroxide value [1, 5]. The physical and chemical properties that are commonly used to evaluate the beeswax quality and distinguish possible adulterations are melting point, Saponification value, acid value, ester value and ester to acid ratio were tested based on the protocols of [6]. The proposed value ranges for the parameters in pure beeswax differ from one country to another [7]. These differences could be related to the point of origin of the beeswax because the environmental and geographical factors play a significant role in the bee adaptation and, as a result, in beeswax composition [8]. 
Presently, because of its high demand and shortage in the world market, its adulteration with cheaper materials became a challenge for its quality and marketing. On the other hand the deterioration of beeswax's natural quality and the alteration of its composition as a result of prolonged over heating during rendering have been reported [3]. Therefore, investigation for the causes of beeswax quality deterioration that is to identify whether it is due to adulteration or inappropriate processing is very important. Until now the physical and chemical properties of local produced beeswax, the type and level of adulterations were not well determined for beeswax in Ethiopia and particularly in Bale.

Therefore, with this justification the present study is expected at determining the quality state of beeswax produced in Bale natural forest in comparison with [10] and [6] standard.

\section{Materials and Methods}

\subsection{Beeswax Sampling and Sample Collection}

Beeswax samples were obtained during December to January, 2015 from beekeepers considering different agroecological variation of Bale (high, mid and low lands).Crude beeswax samples of 1- $3 \mathrm{~kg}$ were randomly collected from 15 beekeepers. The collected samples were refined and purified before analysis and were analyzed based on the protocol of $[6,9]$. The physico-chemical analysis was carried out in the laboratory of Sinana Agricultural Research Center, Soil laboratory Bale-Robe, Ethiopia. To identify the possible quality deteriorating factors the following parameters were used:

\subsection{Specific Gravity}

The specific gravity of beeswax was determined by melting $2 \mathrm{~g}$ of the material in a porcelain crucible at a temperature of about $100^{\circ} \mathrm{C}$. It was allowed to cool down at room temperature. Solidified beeswax was removed from the crucible, warming slightly when necessary. During weighing, beeswax was attached to a tarred silk or similar item that thread was suspended. The sample was stored for 2 hours at a temperature of $20 \pm 1^{\circ} \mathrm{C}$.The mass of sample was determined, first in air and then in rectified spirit maintained at $20 \pm 1{ }^{\circ} \mathrm{C}$. The specific gravity at $20^{\circ} \mathrm{C} / 20^{\circ} \mathrm{C}$ of the rectified spirit was measured by means of the specific gravity bottle,

$$
\text { Specificgravityat20oc } / 20 \mathrm{oc}=\frac{M 1 d}{M 1-M 2}
$$

Where: $\mathrm{M}_{1}=$ mass in $\mathrm{g}$ of the material in air,

$\mathrm{d}=$ specific gravity of rectified spirit, and

$\mathrm{M}_{2}=$ mass in $\mathrm{g}$ of the material in alcohol.

The samples were melted and filtered through fast filter paper to remove any impurities and last traces of moisture. A digital Abbe refractometer $\left(A T A G O^{\circledR}\right.$ Abbe refractometer, made in Japan) was used to determine refractive index. The temperature of the Abbe refractometer was adjusted at $75 \pm 1^{\circ} \mathrm{C}$ by circulating water from the water bath. Few drops of the sample were placed on the lower prism; the prism was closed tightened firmly allowed to stand for one or two minutes. The result of refractive index was read and recorded after the sample had been attained the test temperature.

\subsection{Melting Point}

The melting point of a wax was the temperature at which the wax changes from a solid to a liquid state. The beeswax was melted by warming it in water bath at a temperature just sufficient to melt it and the melting points were determined by the capillary tube method or the drop point method. Melted beeswax was introduced in a $10 \mathrm{~cm}$ long and $2 \mathrm{~mm}$ internal diameter thin-wall hollow capillary tube, until reaching a height of about $1 \mathrm{~cm}$. After that, the capillary tube, containing the beeswax, was introduced into a bath of water that was slowly warmed at $1-2^{\circ} \mathrm{C} / \mathrm{min}$; the temperature was checked with a thermometer (with an accuracy of $0.1^{\circ} \mathrm{C}$ ) whose bulb had to be as close as possible to the beeswax column introduced in the capillary tube.

\subsection{Total Volatile Matter}

To determine the total volatile matter of beeswax, 10 grams of the material were weighed in a suitable dish, previously dried and weighed, and placed it in an oven maintained at $105.2^{\circ} \mathrm{Cfor} 6$ hours. The dish was cooled in desiccators and weighed with the lid on. It was heated again in the oven for 30 minutes. The process was repeated until the loss in mass between two successive weightings was less than one milligram. The result was recorded when the lowest mass has been obtained. Calculation of the results,

TotalVolatilematterat105oc percentbymass

$$
=\frac{100(\mathrm{M} 1-\mathrm{M} 2)}{\mathrm{M} 1-\mathrm{M} 3}
$$

Where: $M_{1}=$ mass in gram of the dish with the material before heating

$\mathrm{M}_{2}=$ mass in gram of the dish after heating

$\mathrm{M}_{3}=$ mass in gram of the empty dish

\subsection{Saponification Value}

The wax (2 g) was dissolved in hot toluene $(910 \mathrm{ml})$. Alcoholic potassium hydroxide (25 $\mathrm{ml}$ of $0.5 \mathrm{M} \mathrm{KOH})$ was added, and the solution is refluxed for 2 hours. A few drops of phenolphthalein were added and the residual potassium hydroxide was titrated with $0.5 \mathrm{M}$ hydrochloric acid. A blank assay or titration was also performed with $25 \mathrm{ml}$ of $0.5 \mathrm{M}$ alcoholic potassium hydroxide plus toluene. The saponification number was the number of milligrams of potassium hydroxide required to hydrolyze $1 \mathrm{~g}$ of wax and determination was made in triplicate. The saponification value, expressed as $\mathrm{mg} \mathrm{KOH} / \mathrm{g}$, was calculated as follows,

$$
\text { SaponificationValue }=\frac{56.1(B-S) N}{M}
$$

Where: $\mathrm{B}=$ volume in $\mathrm{ml}$ of the standard hydrochloric acid 
required for the blank,

$\mathrm{S}=$ volume in $\mathrm{ml}$ of standard hydrochloric acid required for the wax,

$\mathrm{N}=$ normality of standard hydrochloric acid, and

$\mathrm{M}=$ mass in $\mathrm{g}$ of the wax taken for the test.

\subsection{Acid Value}

The acid value was the number of milligrams of potassium hydroxide required to neutralize a gram of the wax. It was determined by the titration of the wax solution in ethanoltoluene with $0.5 \mathrm{M}$ potassium hydroxide. A blank was also titrated to correct solvent acidity. Two drops phenolphthalein is normally added as the titration indicator. The acid value (in $\mathrm{mg} \mathrm{KOH} / \mathrm{g}$ ) was calculated by the formula,

$$
\text { AcidValue }=\frac{56.1 \mathrm{VN}}{\mathrm{W}}
$$

Where:

$\mathrm{V}=$ volume in $\mathrm{ml}$ of standard potassium hydroxide solution used

$\mathrm{N}=$ normality of standard potassium hydroxide solution,

$\mathrm{M}=$ mass in $\mathrm{g}$ of the wax taken for the test.

\subsection{Ester Value}

Ester value was determined by the difference between the saponification value and the acid value and it was showed the amount of potassium hydroxide consumed in the saponification of the esters. Calculation,

$$
\text { EsterValue }=\text { SaponificationValue }- \text { AcidValue }
$$

\subsection{Ester to Acid Ratio}

The ester to acid ratio or ratio number was the number obtained by dividing the ester value by the acid value. Calculation of result,

$$
\text { Rationumber }=\frac{\text { EsterValue }}{\text { AcidValue }}
$$

In the current study all chemicals and reagents used were analytical grade. Then, all parameters were done following the procedure developed/adapted by [6]

\subsection{Data Management and Statistical Analysis}

The obtained data were subjected to statistical analysis using Generalized Linear Model (ANOVA) of SAS version 9.1 (1999). Least significance difference at $\mathrm{P}<0.05$ level was used to separate the means whenever ANOVA showed statistically significant difference. The following analysis of variance model was used for data analysis.

$$
\begin{aligned}
& Y i j=\mu+\alpha i+C i j \\
& \text { Where: Yij = quality of beeswax } \\
& \mu=\text { overall mean } \\
& \alpha i=\text { the effect of the } i^{\text {th }} \text { location } \\
& \epsilon_{i j}=\text { random error }
\end{aligned}
$$

\section{Results and Discussion}

The results of some important physico-chemical analysis of beeswax melting point, specific gravity, refractive index, volatile matter, acid value, saponification value, ester value, and acid to ester ratio of the examined samples are presented.

\subsection{Melting point $\left({ }^{\circ} \mathrm{C}\right)$}

The melting point of beeswax is determined by measuring the temperature at which the first drop of liquid wax appears during heating. It should be between 61 and $66^{\circ} \mathrm{C}$ or preferably between 62 and $65^{\circ} \mathrm{C}[10]$. The melting point of the examined samples ranged from 61.5 to $63.5^{\circ} \mathrm{C}$ with mean of $62.39^{\circ} \mathrm{C}$. Moreover, all of the samples tasted were found within the acceptable limits $61-66^{\circ} \mathrm{C}$ of Ethiopian national standard (Table 1). The result indicated no significant difference $(\mathrm{P}>0.05)$ in melting point among the samples collected from the three districts. Similar result was reported

\begin{tabular}{|c|c|c|c|c|c|c|c|}
\hline \multirow[b]{2}{*}{ Parameter } & \multicolumn{2}{|c|}{ Locations (Mean \pm SE) } & \multirow[b]{2}{*}{ D/menna $(n=5)$} & \multicolumn{2}{|l|}{ Over all } & \multicolumn{2}{|c|}{ Standards* } \\
\hline & Adaba $(n=5)$ & Dinsho $(n=5)$ & & Mean & Range & National & International \\
\hline MP & $62.56 \pm 0.25$ & $62.3 \pm 0.12$ & $62.3 \pm 0.25$ & $62.39 \pm 0.12^{\mathrm{NS}}$ & $61.50-63.50$ & $61-66$ & $62-65$ \\
\hline AV & $23.75 \pm 0.09^{\mathrm{a}}$ & $20.53 \pm 0.45^{\mathrm{c}}$ & $22.72 \pm 0.0 .23^{\mathrm{b}}$ & $22.33 \pm 0.39$ & $19.17-23.84$ & $17-24$ & $17-24$ \\
\hline EV & $76.86 \pm 1.40^{\mathrm{a}}$ & $77.32 \pm 1.22^{\mathrm{a}}$ & $72.50 \pm 0.76^{\mathrm{b}}$ & $75.58 \pm 0.84$ & $70.12-80.41$ & $70-80$ & $72-80$ \\
\hline EAR & $3.24 \pm 0.05^{\mathrm{b}}$ & $3.70 \pm 0.08^{\mathrm{a}}$ & $3.20 \pm 0.06^{\mathrm{b}}$ & $3.38 \pm 0.07$ & $3.0-3.95$ & $3.3-4.2$ & $3.3-4.2$ \\
\hline SV & $100.61 \pm 1.47^{\mathrm{a}}$ & $98.23 \pm 1.27^{\mathrm{ab}}$ & $95.28 \pm 0.62^{b}$ & $98.04 \pm 0.86$ & $93.50-104.25$ & $80-105$ & $>65$ \\
\hline Sp.gr. & $0.9625 \pm 0.003^{\mathrm{a}}$ & $0.9565 \pm 0.001^{\mathrm{b}}$ & $0.9604 \pm 0.001^{\mathrm{ab}}$ & $0.9598 \pm 0.001$ & $0.9549-0.9743$ & - & - \\
\hline RI & $1.4424 \pm 0.0002$ & $1.4425 \pm 0.0004$ & $1.4428 \pm 0.0004$ & $1.4426 \pm 0.0002^{\mathrm{NS}}$ & $1.4410-1.4440$ & - & - \\
\hline VM & $0.3084 \pm 0.031$ & $0.3078 \pm 0.045$ & $0.3842 \pm 0.060$ & $0.3335 \pm 0.027^{\mathrm{NS}}$ & $0.1520-0.4980$ & - & - \\
\hline
\end{tabular}
by [4] of Ethiopian beeswax melting point mean of 62.5 values. [11] also reported 61.9 to $64.1^{\circ} \mathrm{C}$ melting point for Spanish beeswax. From this result, it is realized that beeswax produced at Bale natural forest free from contamination and can be used for any type of purposes.

Table 1. Mean comparison of physicochemical properties of beeswax samples collected from three agro-ecologies in Bale and compared with National and International standards $(N=15)$.

$\mathrm{abc}=$ means with different superscripts within a row are significantly different $(\mathrm{P}<0.05), \mathrm{N}=$ Number of sample, $\mathrm{SE}=\mathrm{Standard}$ Error, $=$ not available

Notice: $\mathrm{MP}=$ Melting Point, $\mathrm{AV}=$ Acid Value, EV = Ester Value, EAR = Ester to Acid Ratio, $\mathrm{SV}=$ Sapanification Value,

Sg.gr. $=$ Specific gravity, $\mathrm{RI}=$ Refractive Index, $\mathrm{VM}=$ Volatile Matter

*Source: $[4,8]$ 


\subsection{Specific Gravity}

The specific gravity of beeswax is the ratio of the weight in air of a unit volume of beeswax at a stated temperature to the weight in air of an equal volume of rectified sprit at the stated temperature. It indicates a change of material (beeswax) or possible contamination. The specific gravity of sample collected varied from 0.9549 to 0.9743 with mean value of 0.9598 . The sample collected from Adaba (0.9625) was significantly higher $(\mathrm{P}<0.05)$ than Dinsho $(0.9565)$ showing that specific gravidity of beeswax influenced by its botanical origin. However, there were no significant difference $(\mathrm{P}>0.05)$ between beeswax samples collected from Dellomenna and Dinsho, Adaba and Dellomena (Table 1). The present result well met the national and international standards and the standards of African Countries like East African standard (0.945 to 0.980$)$ [12], Kenya (0.9500 to $0.9600)$ [13] and other country like India (0.945 to 0.980$)$ [14] showing that the beeswax produced in Bale is of good quality.

\subsection{Refractive Index}

The measurement of refractive index of beeswax is done by means of refractometer and the result meet standard limits of pure beeswax if free of contamination. There were no significant difference $(\mathrm{P}>0.05)$ between the beeswax samples collected from Adaba, Dinsho, and Dellomenna districts in their refractive index. Moreover, the refractive index of collected samples varied from 1.4410 to 1.4440 with mean value of 1.4426 (Table 1) falling within the national and international standards (Table 1). [5] also reported that refractive index ranged from 1.440 to 1.445 which is in line with the present study. In addition, the result was also similar with different countries standard limits Kenya 1.4398 to 1.4455, East African Standard, 1.4405 to 1.4455 and India, 1.4405 to 1.4455$)$ [12-14]. The absence of significant difference $(\mathrm{P}>0.05)$ in between the beeswax samples collected from Adaba, Dinsho, and Dellomenna districts indicates that refractive index of beeswax are not influenced by agro-ecologies.

\subsection{Acid Value (mgKOH/g)}

The acid value is the amount of $\mathrm{KOH}$ milligrams required to neutralize the free acidity present in one gram of bees wax. It is a relative measure of rancidity as free acidity is normally formed during decomposition of beeswax glycerides. It is also determined by directly titration the beeswax in an alcoholic medium against standard $\mathrm{KOH}$ solution. The acid value of the collected samples revealed that there was highly significant variations $(\mathrm{P}<0.05)$ among samples from Adaba (23.75), Dinsho (20.53) and Dellomenna (22.72) (Table 1). The overall values ranged from 19.17 to 23.84 with mean of 22.33 (Table 1). The current result is similar with [4] where the mean result report of Ethiopian beeswax was presented as 21.66. [5] also reported $18-23$ the requirement of pure beeswax from Switzerland. The acid value variations of the beeswax samples collected from the three district indicates the influence of agroecology over the acid value of beeswax and the falling of the tests within national and international range suggests beeswax from Bale are natural (free of contamination).

\subsection{Ester Value (mgKOH/g)}

The ester value of beeswax determined by the difference between saponification value and acid value which indicate the amount of $\mathrm{KOH}$ consumed during saponification of esters and the result must met standard limit to show absence of contamination. The mean result of ester value examined for the beeswax collected from the three districts was 75.58 with minimum 70.12 and the maximum $80.41 \mathrm{mgKOH} / \mathrm{g}$. The average beeswax ester value of Dellomenna (72.50) was significantly lower $(\mathrm{P}<0.05)$ than that of Adaba $(76.86)$ and Dinsho (77.32) districts, suggesting that lowland beeswax lower in saponifiable matter. However, there were no significant difference $(\mathrm{P}>0.05)$ between Adaba and Dinsho districts (Table 1) which shows that similar in ester value. The current result meets the quality standard limits of national and international (Table 1). [4] reported that Ethiopian beeswax ester value ranges 66.38 to 93.03 with mean value of 77.89. [5] also mentioned similar finding that ranged 70 to $80 \mathrm{mg} \mathrm{KOH} / \mathrm{g}$ in Switzerland and [1] reported a little lower value $(62.7$ to $74.8 \mathrm{mg} \mathrm{KOH} / \mathrm{g})$ than present result in Spain.

\subsection{Saponification Value (mgKOH/g)}

The saponification value (number) is the number of milligrams potassium hydroxide required to hydrolyze $1 \mathrm{~g}$ of the sample and is measure the amount of saponifiable matter present. Testing saponification value indicates the number of acids and ester group found in beeswax. The present study indicated significant difference $(\mathrm{P}<0.05)$ among beeswax samples collected from Adaba and Dellomenna districts, and no significant difference $(\mathrm{P}>0.05)$ between Adaba and Dinsho, Dinsho and Dellomenna districts (Table 1). The overall mean of Saponification value was 98.04 ranging from 93.50 to 104.25 (Table 1), falling within the standard limits of national and international (Table 1). [1] reported 92.0 mean saponification value for Spain pure beeswax which is in line with the present result and from the same country [11] reported saponification value that ranged from 90.1 to 98.3 complying with the present study to affirm absence of anomalous value which means free from any adulterants of beeswax.

\subsection{Ester to Acid Ratio}

The ratio of ester values to acids, a parameter determined that gives information whether pure natural beeswax is changed significantly by prolonged or excessive heating beyond the limits set for pure beeswax. The eater to acid ratio of beeswax samples collected from Dinsho district (3.70) was significantly $(\mathrm{P}<0.05)$ higher than that of beeswax samples collected from Adaba (3.24) and Dellomenna (3.20) districts. 
However, there was no significant difference $(\mathrm{P}>0.05)$ between Adaba and Dellomenna districts and the overall mean was 3.38 with the range from 3.0 to 3.95 (Table 1). Similarly [4] reported that Ethiopian beeswax ester to acid ratio ranges 2.91 to 6.20 with mean of 3.64 values. [1] also reported similar results 3.09 to 4.25 values from Spain for pure beeswax suggesting the present result shows that Bale's beekeepers produce natural and pure beeswax that is free from contaminants.

\subsection{Volatile Matter}

The volatile matter is the weight loss percent of beeswax when heated in reducing atmosphere (out of air contact). It indicates the amount of volatile matter lost on heating. The volatile matter of the collected beeswax samples ranged from 0.1520 to 0.4980 with mean value of 0.3335 (Table 1 ), all falling within the national and international standards limit. According to the present results, the difference between volatile matter of the beeswax samples were non-significant $(\mathrm{P}>0.05)$ (Table 1) suggesting that agro-ecology have no influence on volatile matter of natural beeswax. Moreover, the present finding agrees with standard limits of Indian $(0.75$ max) and East African (0.75max) [12, 14] suggesting the beeswax produced in Bale is of good quality.

\section{Conclusions and Recommendations}

The laboratory examination results of the study revealed that all of the beeswax samples collected and tested for major beeswax quality parameters met the requirements of beeswax national and international standards. Therefore, it is advised to exploit the potentials for export market with better improved technology interventions.

\section{Acknowledgements}

The authors would like to acknowledge the Sinana Agricultural Research Center for material and financial supports. Also, we would like to thank the Sinana Agricultural Research Center, Soil Laboratory for its chemicals and equipments support for analysis and the staff of the Sinana Agricultural Research Center for their assistance during the whole work.

\section{References}

[1] Bernal J. L, Jiménez J. J, Delnozal M. J, Toribio L, Martín M. T. (2005). Physico-chemical parameters for the characterization of pure beeswax and detection of adulterations Department of Analytical Chemistry, Faculty of Sciences, University of Valladolid, Spain. European Journal of Lipid Science and Technology, 107: 158-166.

[2] Anam. O. O. and Gathuru E. M (1985). Melting point and saponification cloud point of adulterated beeswax. Proceedings of 3rd International conference on apiculture in tropical climate, 1984, pp 222-223 Nairobi, Kenya.

[3] Tulloch, A. P. (1980). Beeswax composition and analysis. Bee World. v 61, pp 47-62.

[4] Nuru Adgaba (2007). Physical and Chemical properties of Ethiopian beeswax and detection of adulteration. Ethiopian journal of Animal Production, volume 7, Number 1, pp 39-48.

[5] Bogdanov S. (2004) Beeswax: quality issues today. Bee World 85: 46-50.

[6] American Beeswax Importers and Refiners Association Inc. (1968).The United States Pharmacopeia-24/National Formulary-19, National Publishing, New York, USA, pp. $2536-2537$.

[7] United States Pharmacopoeial Convention, Inc.,(2000). National Publishing. National Formulary, 19, 2537.

[8] Tulloch, A. P, Hoffman L. L, (1972). Canadian beeswax: analytical values and composition of hydrocarbons, free acids and long chain esters. J Am Oil Chem Soc, 49, 696-699.

[9] Bonreh Serra J. and Bormejo Orantes F. J. (2011). Detection of adulterated commercial Spanish beeswax. Food Chemistry, http:// www.elsevier.com/locate/foodchem.

[10] Ethiopian Standard (2005). Beeswax-Specification. First edition, ES 1203.

[11] Krell R. (1996). Value added products from bee keeping. FAO Agricultural Services Bulletin, 124. Food and Agricultural Organization of the United Nations. Rome, Italy, $371 \mathrm{p}$.

[12] EAS (East African Standard) (2010). Beeswax - crude and refined Specification. www.eachq. Org.

[13] Kenya Standard (2013). Specification for natural beeswax. CD/05 - 1279, ICS 67.120.

[14] Indian Standard (2007). Beeswax, Crude and Refined Specification (Third Revision) res, 65.140.10; 75.140, https://law.resource.org/pub/in/bis/S06is.1504.1996. 